Creating Productive and Upcoming Sport Education Profesional Hmzanwadi University Vol.4, No.1, Juni 2021, Hal. 19-31

e-ISSN 2614-8781

\title{
HUBUNGAN AKTIVITAS FISIK DENGAN INDEKS MASSA TUBUH PADA ANAK DI DAERAH KAMPUNG NELAYAN PESISIR PANTAI KENJERAN
}

\author{
Bayu Prasetio $^{1}$, Indra Himawan Susanto ${ }^{2}$ \\ email: $\underline{\text { bayu.17060484050@mhs.unesa.ac.id }}{ }^{1}, \underline{\text { indrasusanto@ } \text { unesa.ac.id }^{2}}$ \\ ${ }^{\mathbf{1 , 2}}$ Ilmu Keolahragaan, Fakultas Ilmu Olahraga, Universitas Negeri Surabaya
}

\begin{abstract}
Abstrak
Prevalensi obesitas anak di seluruh dunia telah meningkat pesat selama 3 dekade terakhir. Bahaya yang mengancam anak bukan hanya kelebihan berat badan atau obesitas tetapi juga kekurangan gizi masih merupakan penyakit yang menyerang balita di negara berkembang. Penelitian ini bertujuan untuk mengetahui ada tidaknya hubungan aktivitas fisik dengan indeks massa tubuh anak di daerah kampung nelayan pesisir pantai Kenjeran Kota Surabaya. Penelitian ini dilakukan dengan menggunakan metode cross sectional. Penelitian yang dilakukan di wilayah kampung nelayan pesisir pantai Kenjeran Kota Surabaya ini menggunakan subjek penelitiannya adalah kanak-kanak yang berada di daerah tersebut yang berjumlah 105 orang. Teknik purposive sampling adalah teknik yang digunakan untuk pengambilan sampel. Dalam penelitian ini, angket PAQ-C digunakan sebagai instrumen untuk mengukur aktivitas fisik sedangkan untuk mengukur indeks massa tubuh yang terdiri dari tinggi badan dan berat badan menggunakan instrumen microtoise dan timbangan digital. Teknik analisis data menggunakan korelasi rank spearman dengan taraf signifikansi $<0,05$. Hasil analisis korelasi koefisien sebesar - 0,41 dan juga mendapatkan hasil signifikansi sebesar 0,680. Hasil signifikan > 0,05. Kesimpulan dari hasil penelitian ini adalah bahwa tidak terdapat hubungan yang signifikan antara variabel Aktivitas fisik dengan Indeks massa tubuh anak di daerah kampung nelayan pesisir pantai Kenjeran, Kota Surabaya.
\end{abstract}

Kata kunci: Aktivitas fisik, indeks massa tubuh

\section{Abstract}

The prevalence of child obesity worldwide has increased rapidly over the past 3 decades. The danger that threatens children is not only overweight or obesity but also malnutrition is still a disease that attacks children under five in developing countries. This study aims to determine whether there is a relationship between physical activity and body mass index of children in the coastal fishing village of Kenjeran, Surabaya City. This research was conducted using cross sectional method. The research, which was conducted in the coastal fishing village of Kenjeran, Surabaya, used the research subjects were 105 children in the area. Purposive sampling technique is a technique used for sampling. In this study, the PAQ-C questionnaire was used as an instrument to measure physical activity while measuring body mass index consisting of height and weight used microtoise instruments and digital scales. The data analysis technique used Spearman rank correlation with a significance level of $<0.05$. The results of the coefficient correlation analysis are -0.41 and also get a significance result of 0.680 . Significant result > 0.05. The conclusion from the results of this study is that there is no significant relationship between physical activity variables and body mass index of children in the coastal fishing village of Kenjeran, Surabaya City.

Keywords: physical activity, body mass index, coast 


\section{A. Pendahuluan}

Perkembangan atau kemajuan zaman terus berkembang dari tahun ke tahun. Perkembangan zaman ini menyebabkan perubahan dalam dari berbagai bidang seperti pendidikan, ekonomi, social budaya dan diikuti oleh kemajuan teknologi. Kemajuan teknologi terus mengalami percepatan, dan menciptakan masyarakat digital. Kemajuan teknologi akan mengubah tatanan kehidupan manusia menjadi lebih produktif, cerdas dan berkelanjutan, tidak hanya untuk meningkatkan kinerja dan efisiensi serta meningkatkan kualitas kerja. perkembangan teknologi juga memiliki efek positif dan juga negatif untuk manusia (Ngafifi, 2014). Penggunaan teknologi masa kini yang memiliki efek positif dan negatif bagi anak-anak tanpa terkecuali. Peningkatan penggunaan teknologi dapat menurunkan aktivitas fisik seseorang. Anak-anak zaman sekarang kurang melakukan aktivitas fisik atau berolahraga karena anak-anak sekarang lebih suka menggunakan perangkat daripada bermain dengan teman sebayanya. Selain itu, seiring berjalannya waktu khususnya di perkotaan banyak lahan tempat bermain anak yang sudah beralih fungsi menjadi rumah dan bangunan baru, stadion dan pantai menjadi sangat terbatas. Situasi perkotaan dapat membuat anak-anak kesusahan dalam melakukan aktivitas fisik atau olahraga karena takut akan tindak kekerasan dan kejahatan di luar, di jalan padat yang memiliki kemacetan lalu lintas, kurangnya udara yang bersih dan banyak polusi dan minimnya ruang bermain anak (Ega Tri Ramadona, 2018). Pada tahun 2019, diperkirakan 38,2 juta anak di bawah usia 5 tahun mengalami kelebihan berat badan atau obesitas. Persoalan ini biasanya menjadi masalah di negara-negara berpenghasilan tinggi, kelebihan berat badan dan obesitas kini meningkat di negara-negara berpenghasilan rendah dan menengah (terutama di lingkungan perkotaan). Di benua Afrika, jumlah balita yang kelebihan berat badan telah meningkat hampir 24\% sejak tahun 2000. Pada tahun 2019, setengah dari balita yang kelebihan berat badan atau obesitas tinggal di Asia. Pada tahun 2016, lebih dari 340 juta anak dan remaja berusia 5-19 tahun mengalami kelebihan berat badan atau obesitas (who.int, 2020).

Prevalensi kelebihan berat badan dan obesitas pada anak dan remaja usia 5-19 tahun meningkat drastis dari 4\% pada tahun 1975 menjadi lebih dari 18\% pada tahun 2016. Peningkatan pada anak laki-laki dan perempuan juga telah berubah: pada tahun 2016, proporsi anak laki-laki dan perempuan adalah $18 \%$ dan $19 \%$ anak laki-laki mengalami kelebihan berat badan. Pada tahun 1975, kurang dari 1\% anak dan remaja usia 5-19 tahun mengalami obesitas. Pada tahun 2016, lebih dari 124 juta anak dan remaja mengalami obesitas 6\% untuk wanita dan $8 \%$ untuk pria (who.int, 2020). Obesitas pada anak-anak, remaja dan orang dewasa telah muncul sebagai salah satu masalah kesehatan masyarakat yang paling serius di abad ke-21. Prevalensi obesitas anak di seluruh dunia telah meningkat pesat selama 3 dekade terakhir. Peningkatan prevalensi obesitas pada masa kanak-kanak juga menyebabkan munculnya entitas penyakit komorbid terkait obesitas pada usia dini. Obesitas pada masa kanak-kanak dapat berdampak buruk pada hampir setiap sistem organ dan seringkali menyebabkan konsekuensi serius, termasuk hipertensi, dislipidemia, resistensi insulin, disglikemia, penyakit hati berlemak, dan komplikasi psikososial (Güngör, 2014). Bahaya yang mengancam anak bukan hanya kelebihan berat badan atau obesitas tetapi juga kekurangan gizi masih merupakan penyakit yang menyerang balita di negara berkembang. Konsekuensinya parah dan memiliki implikasi yang tidak dapat diubah dan bertahan lama. Ini bertanggung jawab atas kematian tahunan 3,5 juta anak balita di seluruh dunia dan beban penyakit ketiga dari kelompok usia ini. Ini terus menjadi perhatian kesehatan publik dan pembangunan global yang signifikan. Secara global, diperkirakan $16 \%$ anak balita mengalami kekurangan berat badan yaitu, berat badan untuk usia di bawah -2 SD sesuai pedoman (Kemenkes RI, 2011) pada tahun 2011. Perkiraan prevalensi berat badan kurang pada tahun 2011 adalah 17,7\% di Afrika, 21,4\% di Afrika Sub-Sahara, dan 19,3\% di Afrika Timur. 
Lebih dari 25\% anak balita di negara berkembang mengalami kekurangan gizi. Di antara anakanak yang kekurangan gizi ini, hampir tiga perempatnya tinggal di 10 negara di kawasan Afrika Sub-Sahara; Ethiopia dan Nigeria sendiri berbagi 33\% dari beban kawasan (Tosheno et al., 2017).

Aktivitas fisik didefinisikan sebagai setiap gerakan fisik yang dihasilkan oleh otot rangka, yang menyebabkan pengeluaran energi. Aktivitas fisik dapat diklasifikasikan sebagai aktivitas fisik yang terstruktur dan aktivitas fisik tidak terstruktur. Latihan fisik yang terencana atau latihan yang terorganisir yang bertujuan untuk meningkatkan kesehatan, sedangkan latihan fisik kasual yang tidak direncanakan biasanya merupakan hasil dari aktivitas sehari-hari di tempat kerja, di rumah, atau di dalam transportasi (Strath et al., 2013). Mempromosikan tingkat aktivitas fisik yang memadai pada anak-anak adalah hal utama yang menjadi masalah kesehatan masyarakat. Perkiraan terbaru menyarankan kira-kira tiga perempat dari anak-anak dan remaja di Amerika Serikat usia 6 dan 15 tahun gagal memenuhi panduan Aktivitas Fisik untuk rekomendasi orang Amerika setidaknya 60 menit fisik sedang hingga tinggi aktivitas per hari. Selain itu, hampir setengah dari anak-anak dan remaja di Amerika Serikat berusia antara 6 tahun dan 11 tahun terlibat dalam dua jam atau lebih waktu screen time per hari. Tingkat perilaku screen time yang lebih tinggi dari yang direkomendasikan tingkat yang ditetapkan oleh American Academy of Pediatrics (Dunton et al., 2020). Aktivitas yang tidak mencukupi dan perilaku menetap yang berlebihan atau sedentary behavior di antara anak-anak merupakan masalah yang signifikan karena pola perilaku kesehatan di masa kanak-kanak mungkin terjadi bertahan hingga dewasa dan dapat menyebabkan peningkatan risiko untuk sejumlah kondisi kesehatan yang serius misalnya seperti kelebihan berat badan / obesitas, diabetes tipe II, dan sindrom metabolic di masa kanak-kanak dan dewasa nanti (Sultana et al., 2021). Aktivitas fisik menghasilkan peningkatan pengeluaran energi di atas tingkat istirahat, dan tingkat pengeluaran energi terkait langsung dengan intensitas aktivitas fisik. Energi yang dikeluarkan selama aktivitas fisik hanya 1 dari 3 komponen total pengeluaran energi harian terkait. Aktivitas fisik adalah porsi yang paling bervariasi dari total harian pengeluaran energi (Strath et al., 2013). Aktivitas fisik juga dapat mengurangi risiko terkait dengan kelebihan berat badan dan obesitas serta dapat membantu mengurangi tingkat bahaya penyakit cardiovaskular karena aktivitas fisik memegang peran penting dalam menjaga cardiovascular tetap sehat (Koolhaas et al., 2017). World Health Organization (WHO) juga merekomendasikan aktivitas fisik untuk anak-anak dan remaja, aktivitas fisik tersebut meliputi bermain, permainan, olahraga, transportasi, pekerjaan rumah, rekreasi, pendidikan jasmani, atau olahraga terencana, di konteks kegiatan keluarga, sekolah, dan masyarakat. Rekomendasi untuk meningkatkan kebugaran kardiorespirasi dan otot, kesehatan tulang, dan biomarker kesehatan kardiovaskular dan metabolik adalah yang pertama anak-anak dan remaja berusia 5-17 tahun harus mengumpulkan setidaknya 60 menit sedang - aktivitas fisik dengan intensitas kuat setiap hari. Kedua Jumlah aktivitas fisik yang lebih dari 60 menit memberikan tambahan Keuntungan sehat. Ketiga sebagian besar aktivitas fisik harian harus aerobik. Intensitas yang kuat kegiatan harus digabungkan, termasuk yang memperkuat otot dan tulang, minimal 3 kali seminggu (who.int, 2011).

\section{B. Metode}

Penelitian ini menggunakan desain deskriptif kuantitatif dengan menggunakan metode survei. Penelitian ini dilakukan dengan maksud untuk mengetahui hubungan aktivitas fisik dengan indeks massa tubuh pada anak di kampung nelayan pesisir pantai Kenjeran kota Surabaya. Populasi yang digunakan dalam penelitian ini adalah anak-anak yang bertempat tinggal di kampung nelayan pesisir pantai Kenjeran kota Surabaya yang berusia 5-12 tahun 
(tingkat taman kanak-kanak dan sekolah dasar). Sampel dipilih menggunakan teknik purporsive sampling di RW 03, RT01, RT02 dan RT03. Kemudian responden akan dipilih mengikuti kriteria yang sudah dibuat yaitu anak usia 5-12 tahun. Total sampel yang dipilih adalah sebanyak 105 anak. Penelitian ini dilaksanakan pada tanggal 16-18 februari 2021. Penelitian ini mempunyai dua variabel, yaitu variabel terikat dan variable bebas. Variabel terikat dalam penelitian ini adalah aktivitas fisik dan indeks massa tubuh. Kriteria dari aktivitas fisik ini berpedoman dengan Kementerian Kesehatan yaitu aktivitas fisik dilakukan secara Baik, Benar, Terukur dan Teratur (BBTT) sebanyak 3-5 kali dalam seminggu. (Kementrian Kesehatan, 2018) Sedangkan, untuk kriteria dalam indeks massa tubuh mengacu pada (Kementrian Kesehatan, 2019) dengan terdapat 5 kategori mulai dari sangat kurus, kurus, normal, gemuk, sangat gemuk. Variabel bebasnya adalah jenis kelamin, usia dan tingkat pendidikan.

Teknik pengumpulan data untuk mengambil data dari indeks massa tubuh (IMT) menggunakan timbangan berat badan digital untuk mengambil data berat badan dan menggunakan microtoise untuk mengambil data tinggi badan yang selanjutnya data akan di olah untuk mengetahui indeks massa tubuh anak sesuai pedoman dari (Kementrian Kesehatan, 2019) lalu untuk pengambilan data tingkat aktivitas fisik pada anak yaitu menggunakan kuesioner secara daring dengan metode wawancara menggunakan kuisioner Physical Activity Questionnaire For Children $(P A Q-C)$, dimana tanggapan responden terhadap tingkat aktivitas fisiknya adalah sebagai berikut:

1. Peneliti menentukan jumlah anak yang akan menjadi subjek penelitian.

2. Peneliti menerjemahkan kuesioner ke dalam bahasa Indonesia dan mengubahnya sesuai dengan situasi di lokasi penelitian, kemudian melakukan verifikasi kuesioner ahli yang dilakukan oleh dosen tim validator.

3. Peneliti menyebarkan dan mengumpulkan kuesioner yang diisi oleh anak kemudian datanya diolah.

4. Hitungan indeks massa tubuh (IMT) dari bagi berat badan dengan tinggi badan siswa untuk mendapatkan IMT rata-rata sesuai pedoman yang ada.

5. Peneliti mengolah data yang diperoleh yaitu mengategorikan indeks massa tubuh dan tingkat aktivitas fisik siswa untuk menguji korelasi kedua variabel tersebut.

6. Menarik kesimpulan dari hasil pengolahan data dan korelasi antara kedua variabel.

Kemudian, setelah data diperoleh dari responden data tersebut akan dianalisis dan diolah dengan menggunakan Statistical Program for Social Science (SPSS) untuk menguji hubungan antara aktivitas fisik dengan indeks massa tubuh metode yang digunakan ialah uji korelasi spearman rank kemudian data yang sudah diolah akan di proses di dalam komputer yang sudah terinstal Microsoft Office (Word dan Excel) untuk memasukkan data responden dan mengetahui hubungan antara aktivitas fisik dengan indeks massa tubuh. Data hasil pengisian kuisioner PAQ$\mathrm{C}$ oleh responden kemudian harus dicocokan dengan tabel norma penilaian PAQ-C sebagai berikut:

Tabel 1. Norma Penilaian Kuisioner PAQ-C (Sumber: (Kowalski et al., 2004)

\begin{tabular}{ccc} 
No. & Jumlah Nilai & Kategori \\
\hline 1 & 5 & Sangat Tinggi \\
2 & 4 & Tinggi
\end{tabular}


Creating Productive and Upcoming Sport Education Profesional Hmzanwadi University Vol.4, No.1, Juni 2021, Hal. 19-31

e-ISSN 2614-8781

\begin{tabular}{ccc}
3 & 3 & Sedang \\
4 & 2 & Rendah \\
5 & 1 & Sangat Rendah \\
\hline
\end{tabular}

Data hasil pengukuran indeks massa tubuh yaitu data berat badan dan tinggi badan akan dicocokan dengan table kategori berikut ini:

Tabel 2. Kategori Indeks Massa Tubuh Sumber : (Kementrian Kesehatan, 2019)

\begin{tabular}{ccc} 
No. & Kelas Interval & Kategori \\
\hline 1 & $<17,0$ & Sangat Kurus \\
2 & $17,0-18,4$ & Kurus \\
3 & $18,5-25,0$ & Normal \\
4 & $25,1-27,0$ & Gemuk \\
5 & $>27,0$ & Sangat Gemuk \\
\hline
\end{tabular}

\section{Hasil dan Pembahasan}

Hasil Penelitian

1. Karakteristik responden

Berdasarkan tabel 3 karakteristik responden menunjukkan bahwa 58 orang $(55,2 \%)$ berjenis kelamin laki-laki dan 47 orang $(44,8 \%)$ berjenis kelamin perempuan. Selain itu juga, dari hasil observasi juga mendapatkan rentang usia 5-12 tahun. Bisa dilihat pada tabel 3 perolehan data usia menunjukkan bahwa usia anak di daerah kampung nelayan pesisir pantai Kenjeran kota surabaya rentang usia 5-12 tahun menunjukkan bahwa yang memiliki responden paling banyak daripada yang lainnya yaitu rentang usia 5-8 tahun dengan jumlah sebanyak 57 orang $(54,2 \%)$, yang kedua dengan responden yang lebih tua usianya yaitu usia 9-12 tahun sebanyak 48 orang $(45,8 \%)$. Selanjutnya bisa kita lihat di dalam table 3 dari hasil pengambilan data yaitu pada tingkatan pendidikan taman kanak-kanak (TK) mendapatkan data sebanyak 30 orang $(28,6 \%)$ di ikuti dengan tingkat pendidikan Sekolah Dasar yaitu kelas 1-3 SD sebanyak 45 Orang (42,8\%) dan pada tingkatan kelas 4-6 SD sebanyak 28 orang $(28,6 \%)$ dengan penyebaran responden di wilayah RW 03, RT01, RT02 dan RT03 di kampung nelayan pesisir pantai Kenjeran Kota Surabaya.

Tabel 3. Karakteristik responden

\begin{tabular}{ccc}
\hline & \multicolumn{2}{c}{$\mathrm{n}=105$} \\
\cline { 2 - 3 } Karakteristik Responden & $\mathrm{n}$ & $\%$ \\
\hline Jenis Kelamin & & \\
Laki-laki & 58 & 55,2 \\
Perempuan & 47 & 44,8 \\
Usia & & \\
5-8 Tahun & 57 & 54,2 \\
9-12 Tahun & 58 & 45,8 \\
Tingkat Pendidikan & & \\
TK & 30 & 28,6 \\
1-3 SD & 45 & 42,8 \\
4-6 SD & 28 & 28,6 \\
\hline
\end{tabular}


2. Indeks Massa Tubuh

Hasil dari penelitian ini yaitu bisa dilihat berdasarkan gambar 1 untuk menggambarkan bagaimana kondisi indeks massa tubuh anak di daerah kampung nelayan pesisir pantai Kenjeran, kota Surabaya. Hasil perhitungan dari data indeks massa tubuh yang diperoleh ialah sebanyak 81 orang $(77 \%)$ dalam kategori sangat kurus, sebanyak 9 orang (9\%) dalam kategori kurus, sebanyak 13 orang (12\%) dalam kategori normal, sebanyak 2 orang $(2 \%)$ dalam kategori sangat gemuk. Hasil perhitungan dari data indeks massa tubuh diperoleh rata-rata $($ mean $)=15,842$. Hasil perbandingan indeks massa tubuh laki-laki dan perempuan menunjukkan kategori sangat kurus menunjukkan nilai 44 (42\%) untuk laki-laki dan 37 (35\%) untuk perempuan, kategori kurus menunjukkan nilai $5(5 \%)$ untuk laki-laki dan $4(4 \%)$ untuk perempuan, kategori normal menunjukkan nilai $7(7 \%)$ untuk laki-laki dan 6 $(6 \%)$ untuk perempuan, kategori sangat gemuk menunjukkan nilai 2 (2\%) untuk laki-laki sedangkan perempuan mendapatkan nilai 0 .

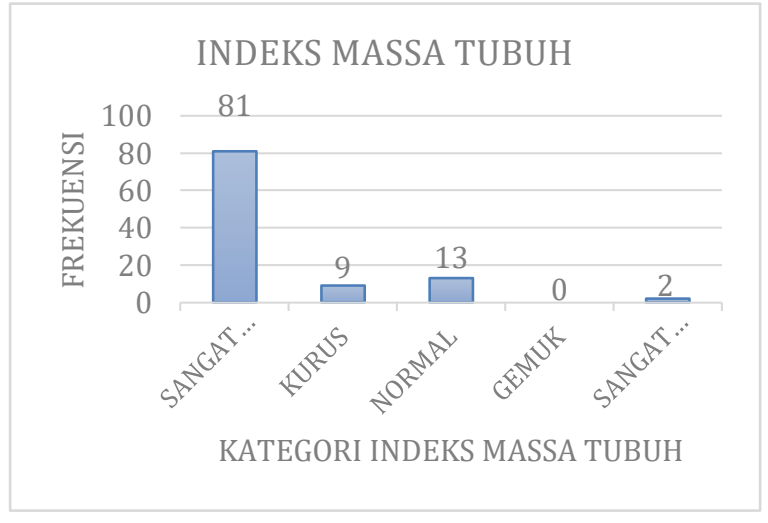

Gambar 1. Indeks Massa Tubuh

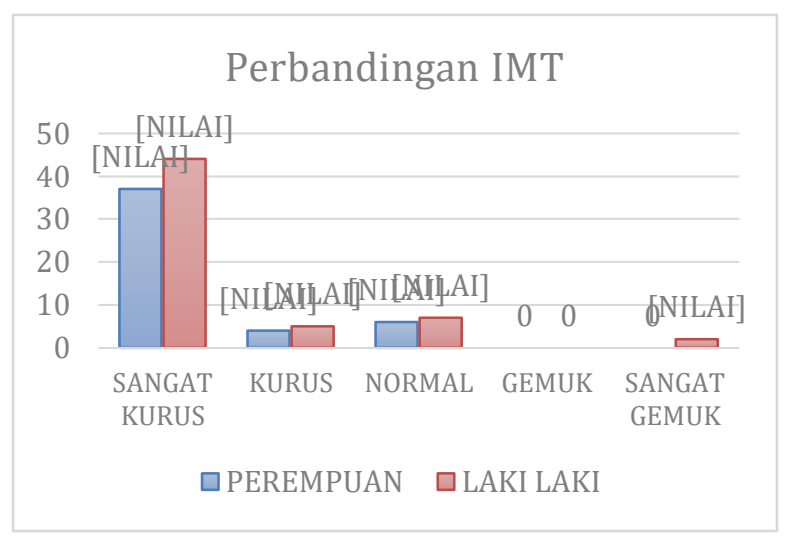

Gambar 2. Perbandingan Indeks Massa Tubuh

\section{Aktivitas Fisik}

\section{a. Kegiatan Aktivitas Fisik}

Hasil dari Penelitian ini menemukan bahwa mayoritas anak di daerah kampung nelayan pesisir pantai Kenjeran kota Surabaya ini selama seminggu terakhir melakukan kegiatan seperti jalan sebanyak 84 orang $(80 \%)$ melakukannya lebih dari 6 kali dalam satu minggu, bersepeda sebanyak 61 orang (58\%) melakukannya lebih dari 6 kali dalam satu minggu, jogging atau lari sebanyak 82 orang (78\%) melakukannya lebih dari satu minggu dan berenang sebanyak 77 kali (73\%) melakukannya lebih dari 6 kali dalam satu minggu.

Tabel 4. Kegiatan Aktivitas Fisik

\begin{tabular}{ccc}
\hline \multirow{2}{*}{ Kegiatan Aktivitas Fisik } & \multicolumn{2}{c}{$\mathrm{n}=105$} \\
\cline { 2 - 3 } Jalan & $\mathrm{n}$ & $\%$ \\
\hline Tidak melakukan & 3 & $3 \%$ \\
1-2 Kali & 7 & $7 \%$ \\
3-4 Kali & 6 & $6 \%$ \\
5-6 Kali & 5 & $28 \%$ \\
Lebih dari 6 kali & 84 & $80 \%$
\end{tabular}




\begin{tabular}{ccc} 
Bersepeda & & \\
Tidak melakukan & 18 & $17 \%$ \\
1-2 Kali & 12 & $11 \%$ \\
3-4 Kali & 10 & $10 \%$ \\
5-6 Kali & 4 & $4 \%$ \\
Lebih dari 6 kali & 61 & $58 \%$ \\
Jogging/Lari & & \\
Tidak melakukan & 3 & $3 \%$ \\
1-2 Kali & 6 & $6 \%$ \\
3-4 Kali & 8 & $8 \%$ \\
5-6 Kali & 6 & $6 \%$ \\
Lebih dari 6 kali & 82 & $78 \%$ \\
Berenang & & \\
Tidak melakukan & 15 & $14 \%$ \\
1-2 Kali & 9 & $9 \%$ \\
3-4 Kali & 2 & $2 \%$ \\
5-6 Kali & 2 & $2 \%$ \\
Lebih dari 6 kali & 77 & $73 \%$ \\
\hline
\end{tabular}

Bagian ini menyajikan hasil kegiatan. Hasil kegiatan dapat dilengkapi dengan tabel, grafik (gambar), dan/atau bagan. Bagian pembahasan memaparkan hasil kegiatan, hasil pengolahan data, menginterpretasikan penemuan atau kemanfaatan secara logis, mengaitkan dengan sumber rujukan yang relevan.

\section{b. Tingkat Aktivitas Fisik Sehari-hari}

Tingkat aktivitas fisik perharinya dapat kita lihat melalui gambar 3, hasil analisis data dari variable tingkat aktivitas fisik sehari hari yang diperoleh dari responden anak di wilayah kampung nelayan pesisir pantai Kenjeran kota Surabaya ini mendapatkan hasil dari penjumlahan dari tingkat aktivitas fisik anak selama sehari hari yaitu pada hari senin dengan skor 344, hari selasa dengan skor 362, hari rabu dengan skor 358, hari kamis dengan skor 360 , hari jum'at dengan skor 369, hari sabtu dengan skor 370 dan hari minggu dengan skor 390.

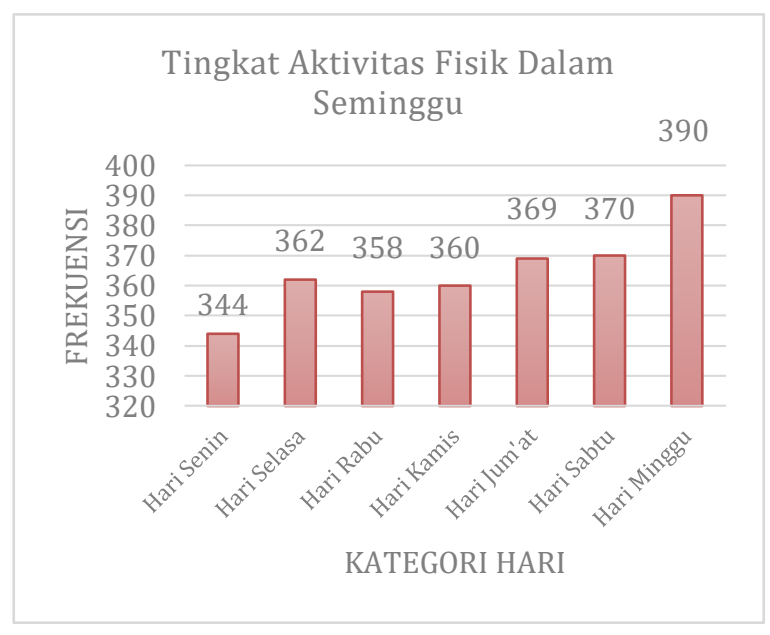

Gambar 3. Tingkat Aktivitas Fisik Sehari-hari 
c. Kategori Tingkat Aktivitas Fisik

Hasil analisis data dari variable tingkat aktivitas fisik yang diperoleh dari responden anak di wilayah kampung nelayan pesisir pantai Kenjeran kota Surabaya. Bisa dilihat berdasarkan gambar 2 yaitu hasil dari analisis data menunjukkan aktivitas fisik anak di daerah kampung nelayan pesisir pantai Kenjeran kota Surabaya ini menunjukkan bahwa 20 orang (19\%) dalam kategori sangat tinggi, sebanyak 29 orang (28\%) dalam kategori tinggi, sebanyak 36 orang (34\%) dalam kategori sedang dan sebanyak 20 orang (19\%) dalam kategori rendah dari hasil analisis data ini juga mendapatkan rata-rata (mean) dari tingkat aktivitas anak adalah 3,422 yang berarti rata-rata anak di daerah tersebut tingkat aktivitas fisiknya masuk kedalam kategori sedang.

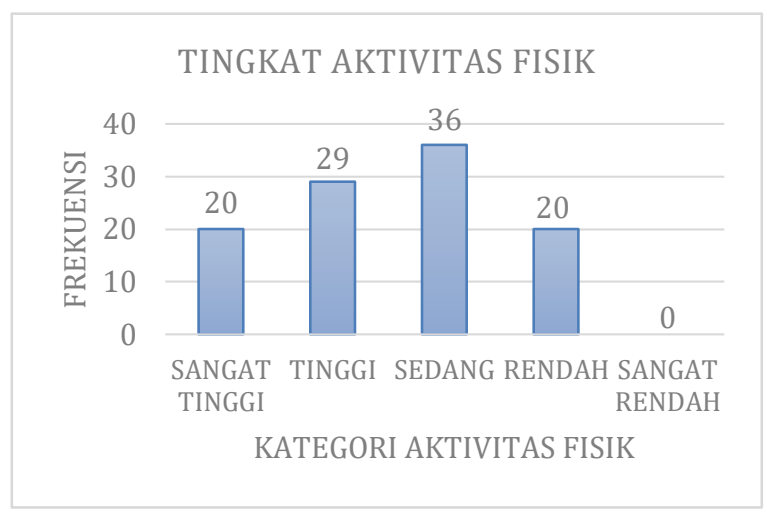

Gambar 4. Tingkat Aktivitas Fisik

4. Hasil Pengujian Hipotesis

Hasil pengujian korelasi Hubungan aktivitas fisik dengan indeks massa tubuh menggunakan uji korelasi Rank Spearman dengan software SPSS 25 dapat dilihat sebagai berikut.

Tabel 5 Analisis Korelasi Rank Spearman, Aktivitas fisik dengan Indeks Massa Tubuh Anak di Kampung Nelayan Pesisir Pantai Kenjeran Kota Surabaya.

Correlations

\begin{tabular}{llccc}
\multicolumn{5}{c}{ Correlations } \\
\hline \multirow{4}{*}{ Spearman's rho } & AK & IMT \\
& Aktivitas & Correlation & 1.000 & -.041 \\
& Fisik & Coefficient & & \\
& & Sig. (2-tailed) &. & .680 \\
& & $\mathrm{~N}$ & 105 & 105 \\
& Indeks & Correlation & -.041 & 1.000 \\
& Massa & Coefficient & & \\
& Tubuh & Sig. (2-tailed) & .680 &. \\
& & $\mathrm{~N}$ & 105 & 105 \\
\hline
\end{tabular}


Menurut data tersebut, kedua variabel tingkat aktivitas fisik dan indeks massa tubuh dapat berkorelasi ataupun tidak. Menggunakan pedoman dari (Latief, 2013) Uji hipotesis dengan membandingkan tingkat signifikansi ( $\mathrm{p}$-value) sebagai berikut:

a. Jika nilai Signifikansi < 0,05 maka Berkorelasi.

b. Jika nilai Signifikansi > 0,05 maka Tidak Berkorelasi.

Uji hipotesis dengan mengukur kekuatan hubungan (Corelation Coefficient) sebagai berikut:

a. $0,00-0,25=$ korelasi sangat lemah.

b. $0,26-0,50=$ korelasi cukup.

c. $0,51-0,75=$ korelasi kuat.

d. $\quad 0,76-0,99=$ korelasi sangat kuat.

e. $1,00=$ korelasi sempurna.

Uji Hipotesis dengan mengukur arah hubungan sebagai berikut:

a. Arah korelasi dilihat pada angka correlation coefficient.

b. Besarnya nilai correlation coefficient antara $+1 \mathrm{~s} / \mathrm{d}-1$.

c. Nilai correlation coefficient bernilai positif, maka hubungan kedua variable searah.

d. Nilai correlation coefficient bernilai negatif, maka hubungan kedua variable tidak searah.

Berdasarkan hasil Statistical Package for the Social Sciences (SPSS) mendapatkan analisis korelasi koefisien sebesar -0,41dan juga mendapatkan hasil signifikansi sebesar 0,680 . Hasil signifikan $>0,05$, yang artinya bahwa tidak terdapat hubungan yang signifikan antara variabel Aktivitas fisik dengan Indeks massa tubuh anak di daerah kampung nelayan pesisir pantai Kenjeran Kota Surabaya.

Pembahasan

1. Aktivitas Fisik

Penelitian di Kampung nelayan pesisir pantai Kenjeran kota Surabaya mendapatkan hasil berupa data tingkat aktivitas fisik anak-anak umur 5-12 tahun di rentang sekolah taman kanak-kanak hingga sekolah dasar ketika di rumah maupun di sekolah dan data indeks massa tubuh anak. Hasil dari penelitian tersebut menunjukkan bahwa tingkat aktivitas fisik yang dilakukan anak-anak di kampung nelayan pada saat di sekolah maupun di rumah cenderung tinggi atau sedang. Pada hasil distribusi frekuensi indeks massa tubuh anak di daerah kampung nelayan tersebut sebagian besar masuk kedalam kategori sangat kurus karena Indeks massa tubuhnya kurang dari yang direkomendasikan oleh (Kementrian Kesehatan, 2019). Berdasarkan dengan pengisian angket survei yang dilakukan oleh peneliti, diperoleh hasil tingkat aktivitas fisik anak di kampung nelayan pesisir pantai Kenjeran Kota Surabaya bahwa mayoritas anak di daerah tersebut masuk kedalam kategori tingkat aktivitas fisik sangat tinggi, kategori tinggi dan kategori sedang sedangkan pada kategori aktivitas fisik rendah dan sangat rendah tidak ada anak yang masuk kedalam kategori ini. Hasil penelitian ini dapat dikatakan sejalan dengan penelitian (Lisbeth, 2013) yang menunjukkan bahwa anak dengan aktivitas rendah memiliki indeks massa tubuh yang lebih tinggi daripada orang normal dan berisiko lebih banyak mengalami masalah gizi.

Aktivitas Fisik anak di daerah kampung nelayan pesisir pantai Kenjeran Kota Surabaya ini banyak berasal dari aktivitas berjalan, bersepeda, berlari dan berenang aktivitas tersebut dilakukan lebih dari 6 (enam) kali dalam kurun waktu satu minggu terakhir hal ini menunjukkan bahwa lebih dari $58 \%$ orang selalu melakukan aktivitas tersebut setiap harinya. Bisa di lihat juga dari hasil penelitian yang menunjukkan bahwa pada hari minggu adalah hari dimana anak-anak memiliki aktivitas fisik yang paling tinggi dengan skor 390 sedangkan pada hari senin menunjukkan penurunan aktivitas anak paling rendah dengan skor 344 . Skor 
ini diambil dari penjumlahan nilai yang di dapat oleh setiap individu responden dan menghasilkan skor tersebut. Responden melakukan latihan fisik minimal 3 hingga lebih dari 6 kali dalam seminggu dengan waktu minimal yaitu 30 menit. Hal ini sesuai dengan ketentuan yang direkomendasikan oleh (Kementrian Kesehatan, 2018) yaitu merekomendasikan latihan fisik selama 30 menit setiap hari atau sekitar 3-5 hari dalam seminggu. Rekomendasi ini dan lainnya ditujukan untuk menjaga tubuh agar tetap sehat dan bugar, sehingga dapat mengurangi stress, meningkatkan suasana hati agar lebih baik, terhindar dari penyakit, dan membakar kalori untuk mencegah kelebihan berat badan dan memperbaiki kualitas tidur. Olahraga yang cukup juga akan mempengaruhi sistem kekebalan dan pertahanan antivirus. (Walsh et al., 2011).

Tingginya tingkat aktivitas fisik disebabkan oleh fakta bahwa anak banyak melakukan aktivitas fisik dan berolahraga di sekolah ataupun di rumah. aktivitas fisik dipromosikan dengan berbagai bahasa permainan (Ashbullby et al., 2013). Saat istirahat, kegiatan yang biasa dilakukan siswa di sekolah antara lain jalan-jalan keliling sekolah, bermain mengejar teman sambal berlari, bermain sepak bola dengan teman, bahkan jarang sekali melihat anak-anak hanya duduk dan santai Ketika jam istirahat. Ini menunjukkan bahwa saat jam istirahat sekolah anak melakukan banyak kegiatan yang tergolong kegiatan dengan intensitas sedang (kegiatan sampai berkeringat). Faktor lain yang dapat mempengaruhi aktivitas fisik anak adalah faktor lingkungan, dan lingkungan sekolah ini sangat mempengaruhi aktivitas anak selama bersekolah. tersedianya sarana dan prasarana yang cukup memadai sebagai tempat untuk berolahraga dan beraktivitas fisik anak juga menjadi dorongan bagi anak untuk selalu dapat melakukan kegiatan aktivitas fisik secara maksimal. Disamping itu lingkungan rumah juga sangat mendukung anak untuk tetap melakukan aktivitas fisik karena bertempat tinggal bersebelahan dengan selat Madura ini anak menjadi memiliki rutinitas kegiatan seperti berenang di sore hari Bersama teman dan kegiatan ini pun di lakukan hampir setiap hari.

2. Indeks Massa Tubuh

Permasalahan penting pada saat ini yaitu masalah mengenai kekurusan dan kegemukan, jika hal ini terus di biarkan maka masalah ini dapat berkembang dan menjadi besar maka harus sesegera mungkin dicarikan jalan keluarnya untuk di selesaikan. Hal ini sejalan dengan hasil RISKESDAS tahun 2018 (Kementerian Kesehatan RI Badan Penelitian dan Pengembangan, 2018). Mengenai masalah kekurusan yang menunjukkan sebesar 12,1\% di tahun 2013 dan sebesar 10,2\% di tahun 2018. Serta mengenai masalah kegemukan yang menunjukkan bahwa masalah kegemukan sebesar 11,9\% di tahun 2013 dan sebesar 8,0\% di tahun 2018 terjadi pada usia 5-12 tahun. Data indeks massa tubuh anak di kampung nelayan pesisir pantai Kenjeran kota surabaya menunjukkan bahwa mayoritas anak di daerah tersebut masuk kedalam kategori sangat kurus. Penelitian ini sejalan dengan penelitian yang dilakukan didaerah pesisir lainnya yang membahas tentang status kesehatan anak sekolah di pedesaan dari pesisir Karnataka negara india (Kulkarni et al., 2016) didalam penelitian tersebut mendapatkan hasil Penelitian yang menunjukkan bahwa terdapat $43,32 \%$ dari anakanak kurus, 53,03\% normal dan 3,65\% kelebihan berat badan. Didukung juga dengan penelitian yang dilakukan oleh (Navaneethan et al., 2011) yang melakukan penelitian di Tamil Nadu negara india, yang mendapatkan hasil bahwa $83 \%$ orang masuk kedalam kategori berat badan kurang, $16 \%$ orang dalam kategori normal dan sisanya $0,45 \%$ masuk kedalam kategori kelebihan berat badan. Dari hasil kedua penelitian tersebut menunjukkan hasil yang kontras dibandingkan dengan hasil dalam penelitian ini. 
Faktor yang mempengaruhi wanita lebih terhindar dari masalah kegemukan dan malah lebih banyak mendapati masalah kekurusan atau kekurangan berat badan, menurut penelitian dari (Kiefer et al., 2005) mengatakan bahwa wanita memiliki kesadaran yang lebih tinggi dan pengetahuan nutrisi yang lebih baik daripada pria. Hal ini sudah muncul mulai dari semasa mereka anak-anak atau remaja. Mereka juga mencari konseling nutrisi lebih sering daripada pria. Wanita lebih banyak makan buah, sayur, sereal, susu, produk susu dan produk biji-bijian, sedangkan konsumsi daging merah, terutama daging sapi, sosis, telur, makanan dengan sukrosa tinggi lebih banyak pada pria. Perbedaan spesifik gender juga terlihat jelas sejauh menyangkut asupan nutrisi dan rekomendasi untuk tunjangan makanan. Pendekatan pria terhadap nutrisi tidak rumit dan berorientasi pada kesenangan sedangkan wanita lebih memiliki sikap ambivalen atau sikap yang bertentangan dengan keinginan dan juga larangan dan akibatnya mereka kurang puas dengan berat badannya. Gangguan makan, diet dan makan yang terkendali jauh lebih sering terjadi pada wanita. Pria, bagaimanapun juga tetap mengontrol berat badan mereka tetapi dengan cara berolahraga dan sesekali menerapkan diet hanya untuk alasan kesehatan. Wanita lebih sering dipengaruhi oleh masalah dengan perilaku makan mereka, seperti keinginan untuk makanan khusus, daripada pria.

Hasil penelitian berdasarkan analisis Rank Spearman menggunakan SPSS 25 dengan nilai signifikansi $<0,05$. signifikansi hubungan aktivitas fisik dan indeks masa tubuh dengan diketahuinya signifikansi atau Sig. (2-tailed) sebesar 0,680, karena nilai Sig. (2-tailed) $0,680>$ lebih besar dari 0,05 , maka artinya tidak ada hubungan antara variable aktivitas fisik dengan indeks massa tubuh anak di kampung nelayan pesisir pantai Kenjeran kota Surabaya. Dari output SPSS ini pula dapat melihat tingkat kekuatan (keeratan) hubungan antara aktivitas fisik dengan indeks masa tubuh, dengan diperolehnya angka koefisien korelasi sebesar -0,041 yang berarti bahwa aktivitas fisik dengan indeks massa tubuh tidak memiliki kekuatan korelasi sama sekali dikarenakan nilai koefisien korelasi -0,041 lebih kecil daripada 0 . Dilihat dari angkat koefisien juga dapat diketahui arah hubungan dari aktivitas fisik dan indeks massa tubuh berdasarkan angka koefisien korelasi pada hasil di atas bersifat negative yaitu $-0,041$, sehingga hubungan kedua variable tersebut bersifat tidak searah (Jenis Hubungan bertolak belakang). Dengan demikian dapat diartikan bahwa kualitas aktivitas fisik semakin ditingkatkan maka tidak akan berdampak pada indeks massa tubuh anak. Hasil tersebut dapat dijelaskan Aktivitas fisik bukan merupakan faktor yang mempengaruhi indeks massa tubuh anak.

\section{Simpulan}

Berdasarkan hasil dari penelitian hubungan fisik dengan indeks massa tubuh anak di daerah kampung nelayan pesisir pantai Kenjeran Kota Surabaya tidak memiliki hubungan yang signifikan terbukti menggunakan analisis data Rank Spearman pada SPSS 25 dengan signifikansi $<0,05$ diperoleh hasil koefisien korelasi sebesar -0,041 dengan signifikansi sebesar 0,680 jadi hubungan antara aktivitas fisik dengan indeks massa tubuh pada anak di daerah kampung nelayan pesisir pantai Kenjeran Kota Surabaya tidak memiliki hubungan dan kekuatan hubungan serta arah hubungan kedua variable ini tidak searah karena nilai korelasi koefisien tersebut bersifat negative. Berdasarkan hasil penelitian dan kesimpulan yang telah di sampaikan tersebut dapat dibuat saran untuk orang tua, anak dan peneliti selanjutnya sebagai berikut:

1. Para orang tua diharapkan dapat memperhatikan pola gizi anak agar anak memiliki gizi yang cukup dan berat badan normal yang sesuai dengan rekomendasi dari kementerian Kesehatan. 
2. Melalui penelitian ini diharapkan anak mampu mempertahankan aktivitas fisik yang baik dan teratur dalam kehidupan sehari hari bahkan dalam proses adaptasi pada kehidupan baru, karena hal ini sangat penting dalam menjaga kesehatan dan kebugaran tubuh.

3. Menggunakan variabel bebas lainnya yang dapat digunakan untuk penelitian ini, sehingga variabel yang mempengaruhi indeks massa tubuh dapat diidentifikasi lebih lanjut.

4. Menggunakan lebih banyak responden untuk mendapatkan hasil yang lebih baik dan maksimal

\section{Daftar Pustaka}

Ashbullby, K. J., Pahl, S., Webley, P., \& White, M. P. (2013). The beach as a setting for families' health promotion: A qualitative study with parents and children living in coastal regions in Southwest England. Health and Place, 23, 138-147. https://doi.org/10.1016/j.healthplace.2013.06.005

Dunton, G. F., Do, B., \& Wang, S. D. (2020). Early effects of the COVID-19 pandemic on physical activity and sedentary behavior in children living in the U.S. BMC Public Health, 20 (1), 1-13. https://doi.org/10.1186/s12889-020-09429-3

Ega Tri Ramadona. (2018). Hubungan Indeks Massa Tubuh Dan Tingkat Aktivitas Fisik Pada Siswa Sekolah Dasar Kelas V Di Sd Negeri Samirono Kecamatan Depok Kabupaten Sleman. 1-26.

Güngör, N. K. (2014). Overweight and obesity in children and adolescents. JCRPE Journal of Clinical Research in Pediatric Endocrinology, 6 (3), 129-143. https://doi.org/10.4274/jcrpe.1471

Kemenkes RI. (2011). KEPMENKES RI Tentang Standar Antropometri Penilaian Status Gizi Anak. In Jornal de Pediatria (Vol. 95, Issue 4, p. 41).

Kementerian Kesehatan RI Badan Penelitian dan Pengembangan. (2018). Hasil Utama Riset Kesehatan Dasar. Kementrian Kesehatan Republik Indonesia, 1-100. http://www.depkes.go.id/resources/download/info-terkini/hasil-riskesdas-2018.pdf

Kementrian Kesehatan. (2018). Mengenal Jenis Aktivitas Fisik. Kementrian Kesehatan Republik Indonesia. https://promkes.kemkes.go.id/content/?p=8807

Kementrian Kesehatan. (2019). Tabel Batas Ambang indeks Massa tubuh (IMT). Kementrian Kesehatan Republik Indonesia. http://www.p2ptm.kemkes.go.id/infographicp2ptm/obesitas/tabel-batas-ambang-indeks-massa-tubuh-imt

Kiefer, I., Rathmanner, T., \& Kunze, M. (2005). Eating and dieting differences in men and women. Journal of Men's Health and Gender, 2 (2), 194-201. https://doi.org/10.1016/j.jmhg.2005.04.010

Koolhaas, C. M., Dhana, K., Schoufour, J. D., Ikram, M. A., Kavousi, M., \& Franco, O. H. (2017). Impact of physical activity on the association of overweight and obesity with cardiovascular disease: The Rotterdam Study. European Journal of Preventive Cardiology, 24(9), 934-941. https://doi.org/10.1177/2047487317693952

Kowalski, K. C., Crocker, P. R. E., Columbia, B., \& Donen, R. M. (2004). The Physical Activity Questionnaire for Older Children ( PAQ-C) and Adolescents ( PAQ-A) Manual. August.

Kulkarni, M., Varun, N., Rathi, P., Eshwari, K., Ashok, K., \& Kamath, V. (2016). Health status of school children in rural area of coastal Karnataka. Medical Journal of Dr. D.Y. Patil University, 9 (1), 31-35. https://doi.org/10.4103/0975-2870.172424

Latief, K. A. (2013). Analisis Koefisien Korelasi Rank Spearman. Analisis Koefisien Korelasi Rank Spearman, 1-27.

Lisbeth, N. (2013). Hubungan Kejadian Obesitas pada Anak dengan Kebiasaan Mengkonsumsi 
Creating Productive and Upcoming Sport Education Profesional Hmzanwadi University Vol.4, No.1, Juni 2021, Hal. 19-31

e-ISSN 2614-8781

Makanan Siap Saji di SDIT. Ulul Albab Bekasi. Jurnal Ilmiah Keperawatan STIKes Medika Cikarang.

Navaneethan, P., Kalaivani, T., Rajasekaran, C., \& Sunil, N. (2011). Nutritional status of children in rural India: a case study from Tamil Nadu, first in the world to initiate the Mid-Day Meal scheme. Health, 03 (10), 647-655. https://doi.org/10.4236/health.2011.310109

Ngafifi, M. (2014). Kemajuan Teknologi Dan Pola Hidup Manusia Dalam Perspektif Sosial Budaya. Jurnal Pembangunan Pendidikan: Fondasi Dan Aplikasi, 2 (1), 33-47. https://doi.org/10.21831/jppfa.v2i1.2616

Strath, S. J., Kaminsky, L. A., Ainsworth, B. E., Ekelund, U., Freedson, P. S., Gary, R. A., Richardson, C. R., Smith, D. T., \& Swartz, A. M. (2013). Guide to the assessment of physical activity: Clinical and research applications: A scientific statement from the American Heart association. Circulation, 128 (20), 2259-2279. https://doi.org/10.1161/01.cir.0000435708.67487.da

Sultana, A., Tasnim, S., Hossain, M. M., Bhattacharya, S., \& Purohit, N. (2021). Digital screen time during the COVID-19 pandemic: a public health concern. F1000Research, 10, 81. https://doi.org/10.12688/f1000research.50880.1

Tosheno, D., Mehretie Adinew, Y., Thangavel, T., \& Bitew Workie, S. (2017). Risk Factors of Underweight in Children Aged 6-59 Months in Ethiopia. Journal of Nutrition and Metabolism, 2017. https://doi.org/10.1155/2017/6368746

Walsh, N. P., Gleeson, M., Shephard, R. J., Gleeson, M., Woods, J. A., Bishop, N. C., Fleshner, M., Green, C., Pedersen, B. K., Hoffman-Goetz, L., Rogers, C. J., Northoff, H., Abbasi, A., \& Simon, P. (2011). Position statement part one: Immune function and exercise. Exercise Immunology Review, 17 (June 2014), 6-63.

Who.int. (2011). Global Recommendations on Physical Activity for Health. WHO. https://www.who.int/health-topics/physical-activity\#tab=tab_1

Who.int. (2020). Obesity and overweight. Www.Who.Int. https://www.who.int/news-room/factsheets/detail/obesity-and-overweight\#: :text=Of these over 650 million adults were obese.,tripled between 1975 and 2016. 